\title{
Deterministic approach for multiple-source tsunami hazard assessment for Sines, Portugal
}

\author{
M. Wronna ${ }^{1}$, R. Omira ${ }^{1,3}$, and M. A. Baptista ${ }^{1,2,3}$ \\ ${ }^{1}$ Instituto Português do Mar e da Atmosfera, IPMA, I. P., Lisbon, Portugal \\ ${ }^{2}$ Instituto Superior de Engenharia de Lisboa, Lisbon, Portugal \\ ${ }^{3}$ Instituto Dom Luiz, University of Lisbon, IDL, Lisbon, Portugal \\ Correspondence to: M. Wronna (martinwronna@gmail.com)
}

Received: 8 June 2015 - Published in Nat. Hazards Earth Syst. Sci. Discuss.: 7 August 2015

Revised: 24 October 2015 - Accepted: 6 November 2015 - Published: 30 November 2015

\begin{abstract}
In this paper, we present a deterministic approach to tsunami hazard assessment for the city and harbour of Sines, Portugal, one of the test sites of project ASTARTE (Assessment, STrategy And Risk Reduction for Tsunamis in Europe). Sines has one of the most important deepwater ports, which has oil-bearing, petrochemical, liquidbulk, coal, and container terminals. The port and its industrial infrastructures face the ocean southwest towards the main seismogenic sources. This work considers two different seismic zones: the Southwest Iberian Margin and the Gloria Fault. Within these two regions, we selected a total of six scenarios to assess the tsunami impact at the test site. The tsunami simulations are computed using NSWING, a Non-linear Shallow Water model wIth Nested Grids. In this study, the static effect of tides is analysed for three different tidal stages: MLLW (mean lower low water), MSL (mean sea level), and MHHW (mean higher high water). For each scenario, the tsunami hazard is described by maximum values of wave height, flow depth, drawback, maximum inundation area and run-up. Synthetic waveforms are computed at virtual tide gauges at specific locations outside and inside the harbour. The final results describe the impact at the Sines test site considering the single scenarios at mean sea level, the aggregate scenario, and the influence of the tide on the aggregate scenario. The results confirm the composite source of Horseshoe and Marques de Pombal faults as the worst-case scenario, with wave heights of over $10 \mathrm{~m}$, which reach the coast approximately $22 \mathrm{~min}$ after the rupture. It dominates the aggregate scenario by about $60 \%$ of the impact area at the test site, considering maximum wave height and maxi-
\end{abstract}

mum flow depth. The HSMPF scenario inundates a total area of $3.5 \mathrm{~km}^{2}$.

\section{Introduction}

Tsunamis are low-frequency but high-impact hazards for coastal societies. The striking tsunami events on 26 December 2004 in the Indian Ocean and on 11 March 2011 in Tohoku raised awareness due to the enormous loss of life and property. The Indian Ocean event in 2004 demonstrated the need for operational early warning systems around the world. However, 7 years later, the 2011 Tohoku event showed the limitations of scientific knowledge concerning tsunami sources, coastal impacts, and mitigation measures. Since then, in the NEAM region (northeast Atlantic, Mediterranean and connected seas) many efforts have been made to understand tsunamigenic sources better and to improve tsunami hazard assessment capabilities. Within the NEAM region, the Gulf of Cadiz is among the most tsunami hazardous areas. The historical reports include events dating back to $60 \mathrm{BC}$ (Mendonça, 1758; Baptista and Miranda, 2009; Kaabouben et al., 2009), but the geological evidence indicates highenergy events as far back as 218 BC (Luque et al., 2001).

The Portuguese coast is highly exposed to tsunami threat from active local and regional tectonic sources. The main tsunamigenic area is the SWIM (Southwest Iberia Margin), with a number of considerable SE dipping inverse faults (Fig. 1b) (Zitellini et al., 2009; Matias et al., 2013). The most severe tsunami occurred on 1 November 1755 and was caused by the Lisbon earthquake, with magnitude of 8.5 as 


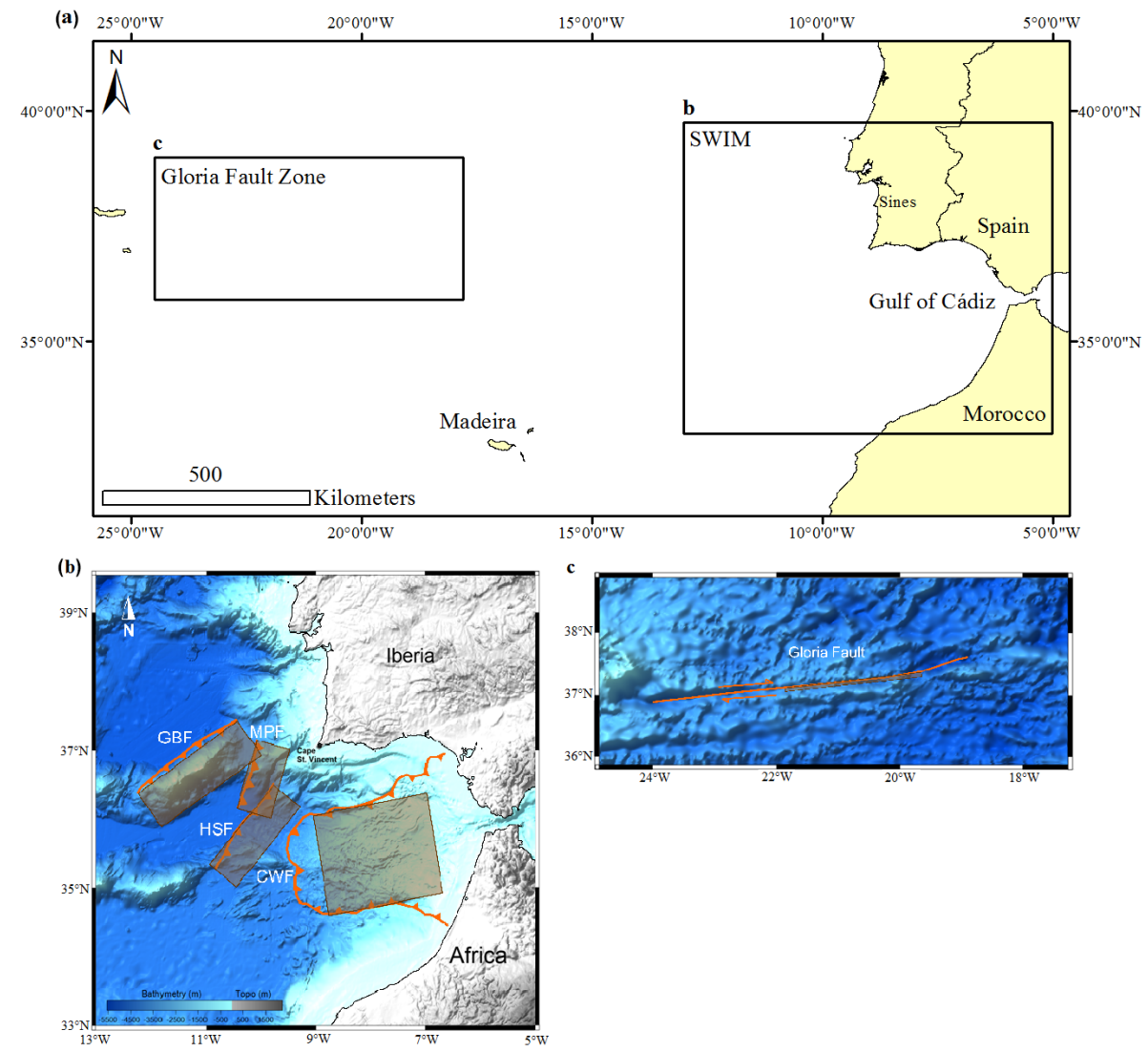

Figure 1. Panel (a): location of the source zones. Panel (b): typical faults (TFs) used for tsunami modelling in the SWIM. Dextral reverse faults: Gorringe Bank fault (GBF), Marques de Pombal fault (MPF), Horseshoe Fault (HSF); subduction slab: Cadiz Wedge fault (CWF). Panel (c): dimension and geographic location of the Gloria Fault (red line) considered in this study. The grey rectangles indicate the fault planes used for modelling.

estimated by Martins and Mendes-Victor (1990). This magnitude was more recently re-evaluated by Solares and $\mathrm{Ar}$ royo (2004), who estimated it to have been $8.5 \pm 0.3$. The tsunami hit the entire northern Atlantic basin with a huge impact in Iberia and Morocco (Fig. 1) (Baptista and Miranda, 2009). In the 20th century, the 28 February 1969 earthquake with a magnitude of 7.9 (Fukao, 1973) caused a small tsunami of $0.5 \mathrm{~m}$ amplitude in Lagos and Cascais (Fig. 2a) (Baptista et al., 1992; Baptista and Miranda, 2009). The tsunami waves hit the coast at circa 03:00 UTC in low-tide conditions (Baptista et al., 1992), but no significant damage was observed.

The second tsunamigenic zone to be considered is the Gloria Fault (Fig. 1c). The Gloria Fault is a segment of the Eurasia-Nubia plate boundary. It is a large strike-slip fault, located between $24^{\circ} \mathrm{W}$ and $19^{\circ} \mathrm{W}$, with scarce seismic activity, but it was nonetheless the location of several large events during the 20th century, in particular the 25 November 1941 earthquake, a submarine strike-slip event of a magnitude of 8.3-8.4 (Gutenberg and Richter, 1949) and the event of 26 May 1975 with a magnitude of 7.9 (Lynnes and Ruff, 1985; Grimson and Chen, 1986).
In recent years, a considerable number of tsunami hazard assessment studies were published for the northeast Atlantic area. Most of these studies focus on the tsunami impact in the Gulf of Cadiz using a deterministic approach, namely Lima et al. (2010), Omira et al. (2010, 2011, 2013), Atillah et al. (2011), Baptista et al. (2011a), Renou et al. (2011), Benchekroun et al. (2015), and Lemos et al. (2014). Recently, Omira et al. (2015) published a probabilistic tsunami hazard assessment for the northeast Atlantic.

In this study, we use a deterministic tsunami hazard assessment (DTHA) approach to evaluate the tsunami impact in Sines (Fig. 2). The study area contains the country's most important deep-water port, which is connected to big industrial complexes by fragile infrastructure such as pipelines and conveyor belts (Fig. 2b). In summer the city is a popular tourist destination.

The DTHA approach consists of studying the impact of specific tsunami events - tsunami scenarios - in the study area. The impact is described in terms of maximum wave height $(\mathrm{MWH})$, maximum flow depth (MFD), maximum drawback (MDB), maximum inundation area (MIA), and maximum inland penetration (MIP). We further built the ag- 


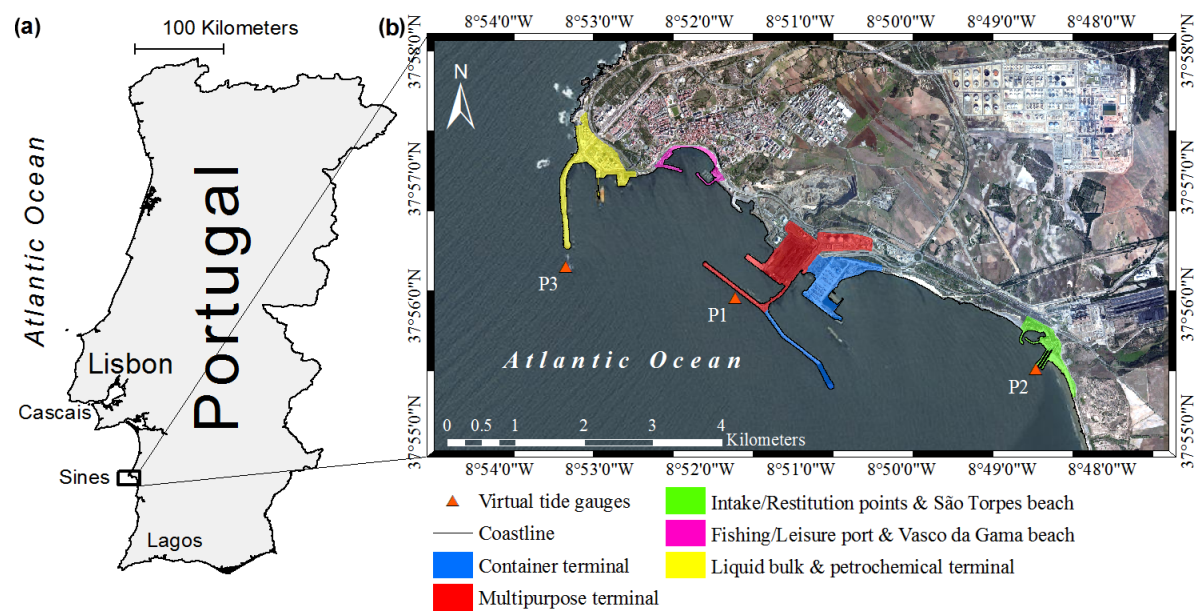

Figure 2. Panel (a): general map, showing location of Sines test site; panel (b): test site map identifying general features and tide gauges for synthetic wave forms.

gregate scenario plotting the MWH and MFD in each cell considering the contribution of the individual scenarios (Tinti et al., 2011).

The final results are presented in integrated hazard maps for all the scenarios considered and for the aggregate scenario. Each integrated hazard map consists of MWH, MFD, MDB, MIA, and MIP of the corresponding scenario. The static effect of the tide is analysed for three different tidal stages: mean lower low water (MLLW), mean sea level (MSL), and mean higher high water (MHHW). Further, we present the contribution of each scenario to the aggregate tsunami impact in MSL conditions.

\section{Study area and digital elevation model}

\subsection{Study area}

Sines is a city located on the west littoral margin of the Iberian Peninsula about $150 \mathrm{~km}$ south of Lisbon (Fig. 2a). The study area includes the city of Sines and parts of the surrounding municipality, covering a coastline of about $35 \mathrm{~km}$. The city has approximately 15000 inhabitants (Instituto Nacional de Estatística, 2011) and a floating population of about 5000 for economic and touristic reasons.

Sines plays a major role in terms of energy production and storage. There are two large production centres of the oil and gas industry (GALP refinery and Repsol YPF petrochemical industrial complex), which are connected via pipelines to oil-bearing and petrochemical terminal of Sines harbour (Câmara Municipal de Sines, 2007). The harbour is the country's most important deep-water port (with $28 \mathrm{~m}$ depth), situated south of the city centre and consists of five terminals - liquidbulk, liquid natural gas, petrochemical, container, and multipurpose - as well as fishing and leisure ports (Porto de Sines, 2014). The liquid natural gas terminal (LNG) contains facili- ties for loading and unloading processes of methane carriers, expedition facilities at the LNG terminal depot, three LNG storage tanks, LNG processing facilities, and natural gas dispatch facilities for the pipeline connecting the Sines LNG terminal to the Natural Gas Transport Network. At the multipurpose terminal, coal is stored in stockpiles and is transported by a conveyor belt to Sines thermoelectric power plant. The power plant uses seawater to cool the generators, and this is captured and returned at the intake and restitution points close to São Torpes beach (Fig. 2b). The majority of the harbour facilities and big areas of the power plant are situated in a possible inundation area below the $25 \mathrm{~m}$ topographic contour. The liquefied natural gas storage deposits are located right behind the port. In the case of a destructive tsunami, facilities or leaking pipelines increase the danger of explosion and may cause an environmental disaster.

The study area limits are $8^{\circ} 47^{\prime} 00^{\prime \prime} \mathrm{W}$ to $8^{\circ} 55^{\prime} 00^{\prime \prime} \mathrm{W}$ and $37^{\circ} 55^{\prime} 00^{\prime \prime} \mathrm{N}$ to $37^{\circ} 58^{\prime} 00^{\prime \prime} \mathrm{N}$. In the northern part the landscape is designed by the influence of the magmatic batholith of Sines with a steep and rocky seafront. The area of the port begins on the southwesternmost part of the rocky outcrops. The main breakwater faces south with a maximum elevation of $15 \mathrm{~m}$ above MSL and a width of $10 \mathrm{~m}$ (Fig. 2b). The liquid-bulk terminal and petrochemical terminal are protected by the breakwater against strong swell reaching the Portuguese coast mainly from northwest. Smaller jetties protect the fishing and leisure ports, which also protect the shellshaped beach "Vasco da Gama" (Fig. 2b). The city centre is located to the north and the majority of domestic property is at the top of the batholith with altitudes of $25 \mathrm{~m}$ above MSL. Further east, the remaining terminals - multipurpose, container, and natural gas - are protected by a recently enlarged breakwater of approximately $2.5 \mathrm{~km}$ length (Fig. $2 \mathrm{~b}$ ). The container terminal is currently under construction due to expansion at the easternmost area of the port, exposing 
new economic value to tsunami threat. The jetties to protect the intake and restitution points of the EDP thermoelectric power plant are situated further southeast on the coast. Right beyond the jetties southwards begins the popular, highly visited beach of "São Torpes", which is already a part of the natural park "Costa Vicentina" (Fig. 2b). The main port areas and Vasco da Gama beach have their coastline facing southwards. The main tsunamigenic sources are located south of the study area. Due to the area's openness and exposure to the sea, the impact of tsunamis and other marine hazards like sea level rise are of great concern.

\subsection{Digital elevation model}

In order to guarantee a good representation of the study area, we built a high-resolution digital elevation model (DEM). We combined three different data sets and set them to the same reference system using GIS tools (geographic information system). We validated the final data set using real-time kinetic GPS on field trips. The DEM is crucial for the computation of inundation on dry land and near-shore propagation.

Different types of data sets were used: a high-resolution LIDAR data set (Direção-Geral do Território, 2011), a bathymetric model (Instituto Hidrográfico de Portugal, 2012), and a nautical chart (Instituto Hidrográfico de Portugal, 2010). The LIDAR data set of 2011 has a resolution of $2 \mathrm{~m}$. The data are available in a PT-TM06/ETRS89 projection and referenced to the altimetric datum of Cascais, $2.08 \mathrm{~m}$ above hydrographic zero. The data set of the bathymetric model contains a grid-based point information of $100 \mathrm{~m}$ spacing based on hydrographic surveys. Where LIDAR data set and the bathymetric model overlap, preference has been given to the more recent and higher-resolution LIDAR data set. For further improvement, the nautical chart of Sines was scanned, geo-referenced, and digitized. The nautical chart of Sines consists of two different charts, one showing a more detailed view of the port with a scale of $1: 12500$ and the general chart of the test site with a scale of $1: 30000$. Depth and altimetry data of the bathymetric model and the nautical charts are referenced to the hydrographic zero. All data were referenced to MSL, which lies $2 \mathrm{~m}$ above the hydrographic zero in Sines. In order to validate the final data sets we used fieldsurveyed data points with GPS-RTK (Global Position System real-time kinetic). In order to fill the gaps of the LIDAR data we used GPS-RTK to collect data and to implement a recently constructed extension of a jetty not yet present in the data sets. After combination, validation, and adaption of the existing data sets, a grid representing the final study area with a $10 \mathrm{~m}$ resolution was computed. The resulting DEM properly represents the Sines test site, especially the near-shore areas, as the LIDAR data set is of a very high resolution. The $10 \mathrm{~m}$ grid represents small rocky outcrops of the batholith in between Vasco da Gama beach and the leisure port. Other features, such as the connection to the main jetty in front of the multi-use, liquid natural gas, and container terminal or the jetty at the leisure port, suffer from the low resolution.

\section{Numerical model and nested grids}

Numerical modelling of tsunamis is commonly divided into three stages: generation, propagation, and inundation. We use a benchmarked numerical code NSWING (Non-linear Shallow Water model wIth Nested Grids) (Miranda et al., 2014) developed in-house to model the tsunami. The model supposes an instant seabed deformation that has been rendered using the half-space elastic theory (Okada, 1985) embedded in Mirone suite (Luis, 2007). The vertical sea bottom deformation is assumed to be equal to the free-surface deformation and transferred to the ocean surface.

The code solves linear and non-linear approximations of shallow-water equations (SWEs) to calculate tsunami propagation and inundation in a Cartesian or spherical reference system. In the deep ocean, non-linear convective inertia forces are of secondary order as waves travel with amplitudes much smaller than water depths. When the tsunami enters shallow coastal areas, the non-linear convective inertia force and bottom friction become increasingly important. We applied non-linear SWEs approximations in all instances, for deep-ocean, near-shore, and onshore propagation.

NSWING employs a dynamically coupled system of nested grids and solves SWEs using an explicit staggered finite leapfrog numerical scheme for linear terms and an upwind scheme for non-linear terms. In NSWING the incorporation of the system-coupled nested grids is mainly based on the code COMCOT (Cornell Multi-grid Coupled Tsunami Model; Liu et al., 1998). The code further applies a radiating boundary condition, allowing wave motion to pass from one domain to another, through boundaries with very small reflections. A moving boundary algorithm (Liu et al., 1995), based on "wet" and "dry" cells, is adopted to track shoreline movement during inundation.

Propagation and behaviour of tsunamis change because of varying bathymetry when they enter coastal areas. To model the impact in Sines, we implement a dynamically coupled system of nested grids. We interpolated the half-minute North Atlantic grid (GEBCO, 2014) to $640 \mathrm{~m}$ resolution for the parent grid. Using four layers and applying a refinement factor of 4 , we achieved a $10 \mathrm{~m}$ final resolution in the DEM.

The amplitude of the tide in southwest Portugal is above $2 \mathrm{~m}$ and must be taken into account in Sines (Baptista et al., 2011a). To study the tide effect, the tidal variation in the last 3 years was considered. We used the values of mean high water (MHW) and mean low water (MLW) from 2012 to 2014 (Antunes, 2014) and calculated the mean to obtain the MHHW and MLLW respectively and referenced them to MSL. The MHHW is $1.22 \mathrm{~m}$ above MSL, and the MLLW is $0.88 \mathrm{~m}$ below MSL. These values have been subtracted and added respectively to the established DEM. For each scenario 
designed, we ran the model in MHHW, MSL, and MLLW conditions to study the static influence of the tide; the result is presented in respect to the aggregate scenario.

\section{Tsunamigenic scenarios}

To design the tsunami scenarios we use the main seismogenic source zones and the associated maximum credible earthquake (MCE) (Miranda et al., 2008; Omira et al., 2009). We used the typical faults (TFs) presented in Omira et al. (2009) except for the Portimao Bank fault (PBF) because it does not direct enough energy to the western Portuguese coast.

The seismogenic sources used here are SWIM and Gloria. For this study we considered four TFs in the SWIM area and their MCE scenarios to reproduce initial conditions for tsunami propagation; these TFs are the Cadiz Wedge fault (CWF), the Gorringe Bank fault (GBF), the Horseshoe Fault (HSF), and the Marques de Pombal fault (MPF) (Fig. 1b). Additionally, we use a seismogenic scenario consisting of a composite rupture of HSF and MPF (HSMPF), proposed by Ribeiro et al. (2006) for the source of the 1 November 1755 earthquake. This source is also stated in Matias et al. (2013), with a maximum magnitude estimation of 8.75. This magnitude value coincides with the upper limit of the magnitude estimate for the 1755 earthquake of Solares and Arroyo (2004): $8.5 \pm 0.3$. As this source has been proposed, we cannot evaluate a worst-case scenario impact without considering it.

The major tsunami event in the SWIM is the one associated with the 1 November 1755 earthquake, and the exact source remains unknown. Numerous studies and campaigns have been carried out in order to identify the source of the 1 November 1755 tsunami. Data (multi-channel reflection seismic, refraction seismic, multibeam swath bathymetry) have been gathered to reveal more accurate information on the tectonics in the SWIM. These investigations in the SWIM revealed much geological evidence for the TFs used in this study. Several authors proposed different sources for this event.

Johnston (1996) suggested the GBF as a possible candidate source of the 1 November 1755 event through scale comparison of isoseismal maps with the 28 February 1969 event. The source for the 1755 tsunami suggested by Baptista et al. (1998) is closer to the Portuguese coast compared to the GBF. Zitellini et al. (1999) found an active thrust fault, the MPF, through the interpretation of multi-channel seismic data. Gutscher et al. (2002) identified an active subduction, the CWF, and concluded that it is a candidate source for the 1755 event. Therefore it must be considered in natural hazard assessments. Further neotectonic structures and deformed seafloor sediments at the HSF also show clusters with shallow seismicity (Gràcia et al., 2003). Some authors suggest considering multiple fault rupture scenarios to explain the high magnitude observed in 1755 (Zitellini et al., 2001;
Gràcia et al., 2003; Ribeiro et al., 2006). As this overview shows, the exact source of the 1755 Lisbon event is still a matter of discussion. These uncertainties related to the 1755 source and the tectonic processes acting in the SWIM confirm the need of systematic tsunami hazard assessment in surrounding areas.

The Gloria zone is our regional source area. The Gloria Fault is a transform fault running from $24^{\circ} \mathrm{W}$ to $19^{\circ} \mathrm{W}$ (Laughton and Witmarsh, 1974). Three strong magnitude earthquakes occurred in the last 130 years: 22 December 1884 (Moreira, 1984), 25 November 1941 - magnitude 8.3 (Gutenberg and Richter, 1949; Moreira, 1984), and 26 May 1975 - magnitude 7.9 (Lynnes and Ruff, 1985; Grimson and Chen, 1986). 25 November 1941 and 26 May 1975 produced small tsunamis recorded at the tide stations in the northeast Atlantic basin (Debrach, 1946; Moreira, 1984; Baptista et al., 1992; Baptista and Miranda, 2009). The 25 November 1941 epicentre location and the focal mechanism are presented in Baptista et al. (2011b). We used these parameters to draw a 1941-like scenario for the Gloria source zone. The TF parameters are presented in Table 1, and the fault is presented in Fig. 1.

\section{Results}

We ran a total of 18 simulations. For each typical fault we considered three tide conditions: MLLW, MSL, and MHHW. The results are presented in the form of integrated hazard maps showing MWH, MFD, MDB, MIA, and MIP (Fig. 3a-e). For the scenarios at MSL, we additionally present synthetic waveforms (Figs. 4 and 5) at chosen positions (Fig. 2b).

In Fig. 6 we present the aggregate scenario, considering all calculated models. Figure 7 shows the inundation and the drawback limits, considering the aggregate scenarios at the three tide conditions.

\subsection{MSL results}

The analysis of Figs. 3-5 shows that all SWIM scenarios produce heavier inundation and drawback in comparison to the Gloria Fault scenario. The Gloria scenario produces MWH values of approximately $1 \mathrm{~m}$, while the SWIM scenarios produce MWHs above $10 \mathrm{~m}$. Figures 3-5 present results of the individual scenarios, and their absolute values are summarized in Table 2. The HSMPF scenario, corresponding to the worst-case scenario, produces an MWH of $18.6 \mathrm{~m}$ and $3.47 \mathrm{~km}^{2}$ of inundated area. Detailed analysis of Fig. $3 \mathrm{~d}$ shows flow depths greater than $0.5 \mathrm{~m}$ in $90 \%$ of the inundation area. The GBF and HSF scenarios, with MWH above $15 \mathrm{~m}$, also produce inundation greater than $3 \mathrm{~km}^{2}$ (cf. Table 2, Fig. 3b and c). The remaining SWIM scenarios (CWF and MPF) still produce MWH above $10 \mathrm{~m}$ and leave more than $2 \mathrm{~km}^{2}$ inundated. 
Table 1. Fault parameters of the tsunamigenic sources considered in this study. These parameters have been used for the three different tides MHHW, MSL, and MLLW.

\begin{tabular}{lrrrrrrrrl}
\hline Fault & $\begin{array}{r}L \\
(\mathrm{~km})\end{array}$ & $\begin{array}{r}W \\
(\mathrm{~km})\end{array}$ & $\begin{array}{r}\text { Rake } \\
\left({ }^{\circ}\right)\end{array}$ & $\begin{array}{r}\text { Strike } \\
\left({ }^{\circ}\right)\end{array}$ & $\begin{array}{r}\text { Dip } \\
\left({ }^{\circ}\right)\end{array}$ & $\begin{array}{r}\text { Slip } \\
(\mathrm{m})\end{array}$ & $\begin{array}{r}\text { Depth } \\
(\mathrm{km})\end{array}$ & $\begin{array}{c}\mu \\
(\mathrm{Pa})\end{array}$ & $M_{\mathrm{W}}$ \\
\hline HSF & 165 & 70 & 90 & 42.1 & 35 & 15 & 5 & $4.5 \times 10^{10}$ & 8.5 \\
MPF & 110 & 70 & 90 & 20.1 & 35 & 8 & 5 & $4.5 \times 10^{10}$ & 8.25 \\
CWF & 170 & 200 & 90 & 349 & 5 & 20 & 5 & $3.0 \times 10^{10}$ & 8.75 \\
GBF & 200 & 80 & 90 & 53 & 35 & 10 & 5 & $4.5 \times 10^{10}$ & 8.5 \\
HSMPF & $165 / 110$ & $70 / 70$ & $90 / 90$ & $42.1 / 20.1$ & $35 / 35$ & $15 / 8$ & $5 / 5$ & $4.5 \times 10^{10} / 4.5 \times 10^{10}$ & 8.75 \\
Gloria & 200 & 50 & 160 & 82 & 88 & 11 & 1 & $3.0 \times 10^{10}$ & 8.3 \\
\hline
\end{tabular}
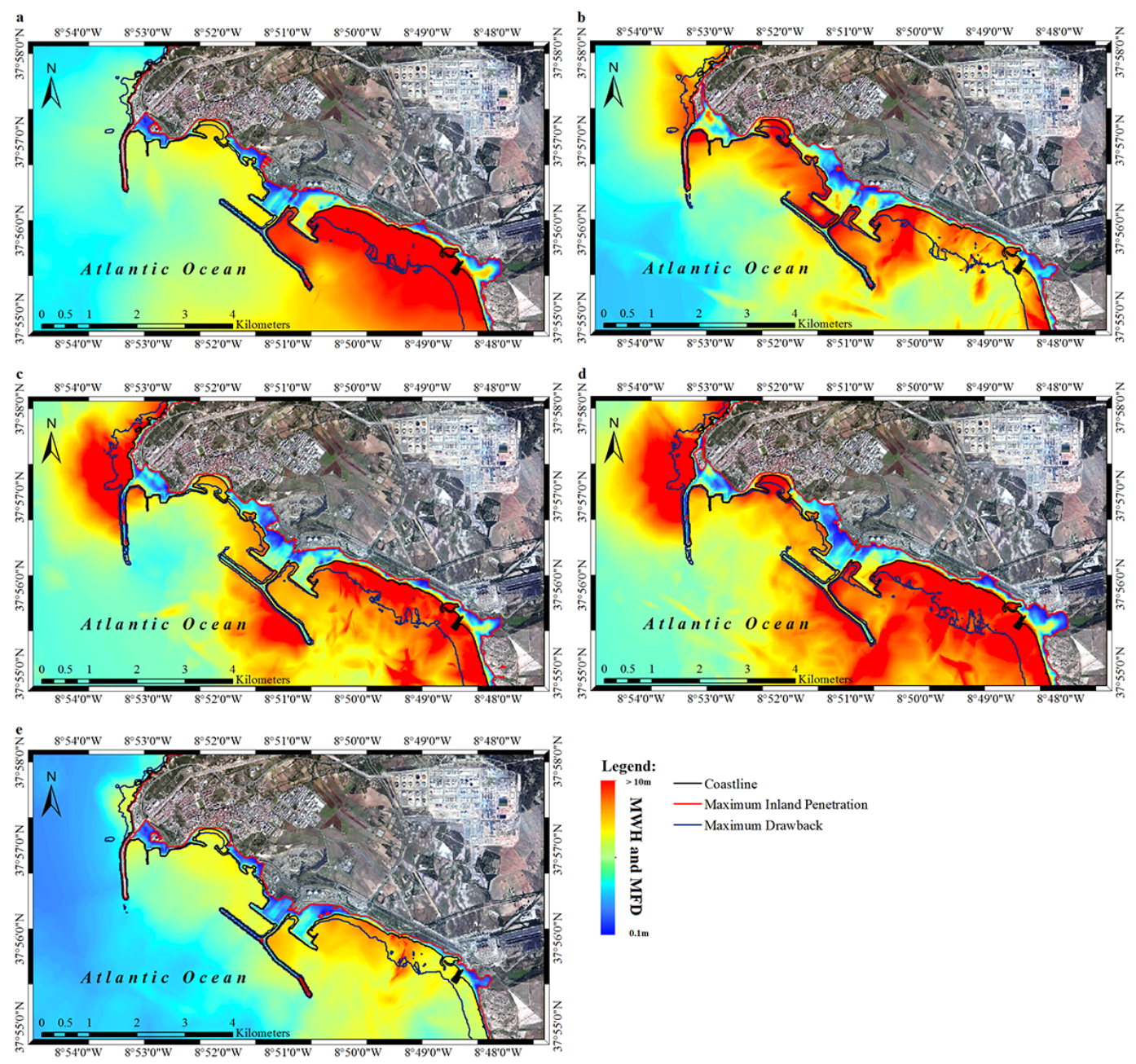

Figure 3. Results of MWH, MFD, MDB, MIA, and MIP of the SWIM scenarios considering MSL: (a) CWF; (b) GBF; (c) HSF; (d) HSMPF; (e) MPF. MWH and MFD are represented by the colour bar in the lower right corner offshore and on land respectively. Offshore and land are separated by the coastline (black line). MDB is indicated by the dark blue line. The MIA is given between the coastline and the MIP (red line).

Among the SWIM scenarios, the MPF produces the weakest impact in Sines but still with MWH above $10 \mathrm{~m}$ (cf. Fig. 3e). Maximum run-up to $19.3 \mathrm{~m}$ occurs during the HSF scenario at the south of the test site (cf. Table 2). All
SWIM scenarios produce sufficient drawback (see blue lines in Fig. 3a-e) to leave the intake and restitution points of the thermoelectric power plant dry. MDB occurs during the composite tsunami model HSMPF. The Gloria scenario produces 

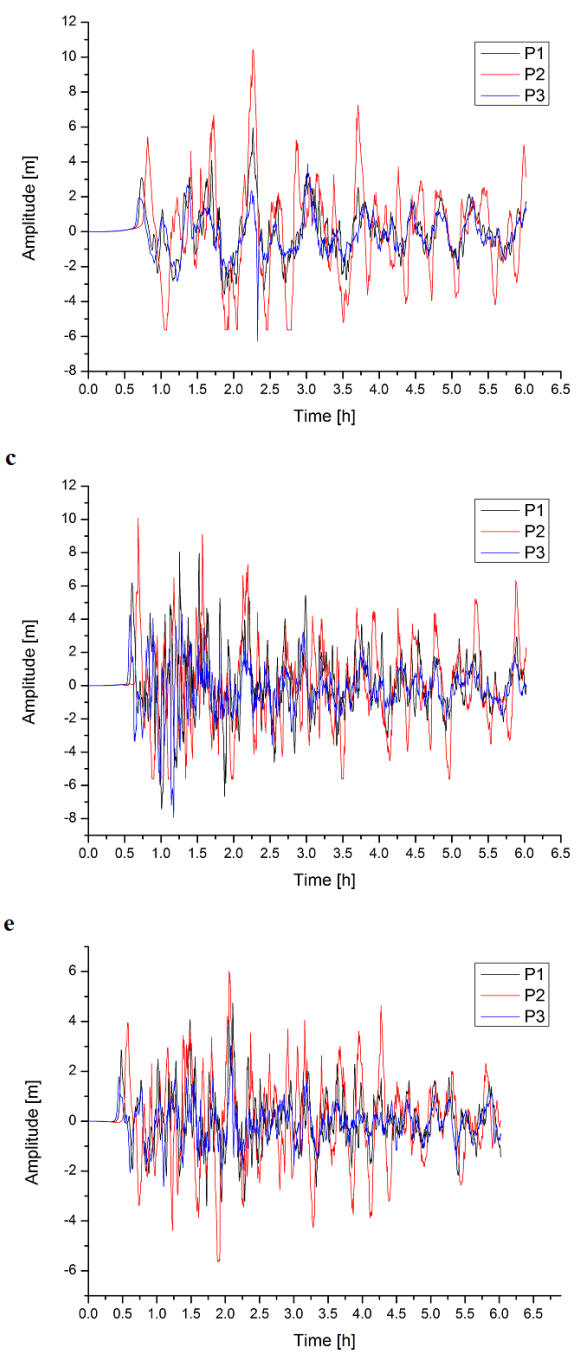

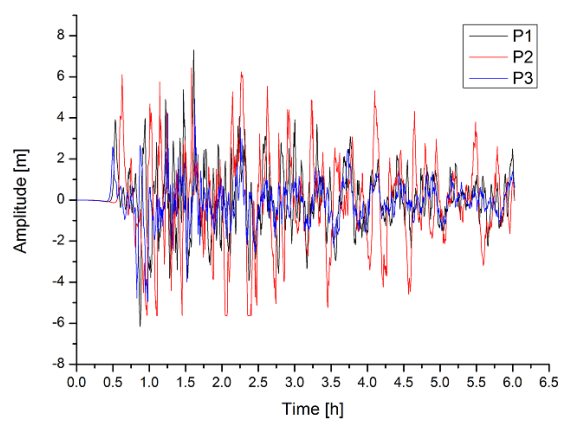

d

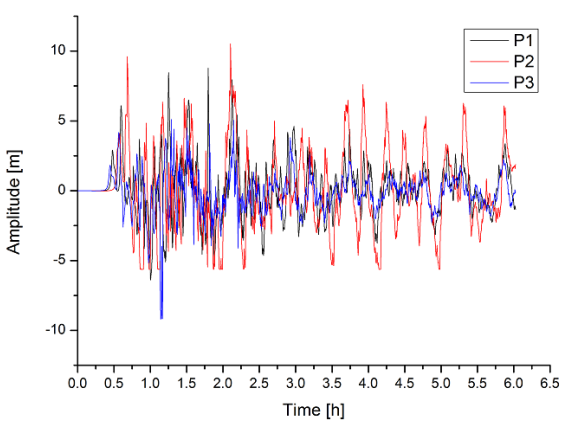

Figure 4. Synthetic waveforms for $6 \mathrm{~h}$ propagation time at three chosen points (cf. Fig. 2) for the SWIM scenarios: (a) CWF; (b) GBF; (c) HSF; (d) HSMPF; (e) MPF.

an MWH of $1.2 \mathrm{~m}$ in certain areas and inundates low-lying areas such as beaches. The flooded area of the Gloria scenario is less than $0.2 \mathrm{~km}^{2}$, and the area at the intake and restitution points does not stay dry (Fig. 5a and Table 2).

The analysis of the synthetic waveforms at the virtual stations shows similar periods and tsunami travel times for all SWIM scenarios (Fig. 4). First arrival occurs in all records at point P3 (blue curves in Figs. 4 and 5b). Clearly distinguishable are the records for the Gloria scenario presented in Fig. 5b, which shows an arrival time of about $85 \mathrm{~min}$ after initial sea surface displacement. The maximum amplitude is about $0.4 \mathrm{~m}$ with a period of approximately $10 \mathrm{~min}$ (Fig. $5 \mathrm{~b}$ ). The record in tide gauge point $\mathrm{P} 2$, at $5.6 \mathrm{~m}$ depth right in front of the intake and restitution points, confirms that no considerable drawback happens throughout the event (Fig. 5b). The records of the SWIM scenarios GBF, HSF, HSMPF, MPF show periods of 15 to $20 \mathrm{~min}$ and for the CWF approximately
Table 2. Synthesis of the results: MFD, MWH, MIA, MDB area, maximum run-up, and arrival time for all scenarios at MSL.

\begin{tabular}{lrrrrrc}
\hline $\begin{array}{l}\text { Scenario } \\
(\text { MSL })\end{array}$ & $\begin{array}{r}\text { MFD } \\
(\mathrm{m})\end{array}$ & $\begin{array}{r}\text { MWH } \\
(\mathrm{m})\end{array}$ & $\begin{array}{r}\text { MIA } \\
\left(\mathrm{km}^{2}\right)\end{array}$ & $\begin{array}{r}\text { MDB } \\
\text { area } \\
\left(\mathrm{km}^{2}\right)\end{array}$ & $\begin{array}{r}\text { Maximum } \\
\text { run-up } \\
(\mathrm{m})\end{array}$ & $\begin{array}{c}\text { Arrival } \\
\text { time } \\
(\mathrm{min})\end{array}$ \\
\hline CWF & 12.2 & 12.8 & 2.71 & 2.98 & 14.1 & 38 \\
HSF & 13.3 & 15.7 & 3.16 & 3.37 & 19.3 & 30 \\
GBF & 12.4 & 17.1 & 3.18 & 3.02 & 18.9 & 25 \\
HSMPF & 13.1 & 18.6 & 3.47 & 3.80 & 17.5 & 22 \\
MPF & 9.1 & 10.7 & 2.07 & 1.98 & 11.3 & 22 \\
Gloria & 0.9 & 1.2 & 0.19 & 0.22 & 4.3 & 85 \\
\hline
\end{tabular}

25 min. Maximum amplitudes are obtained at the tide gauge P2 for the tsunamis produced by CWF at the third wave and by HSF and HSMPF at the first and third wave respectively. At point $\mathrm{P} 2$ waveforms indicate that the cell stays dry at least 

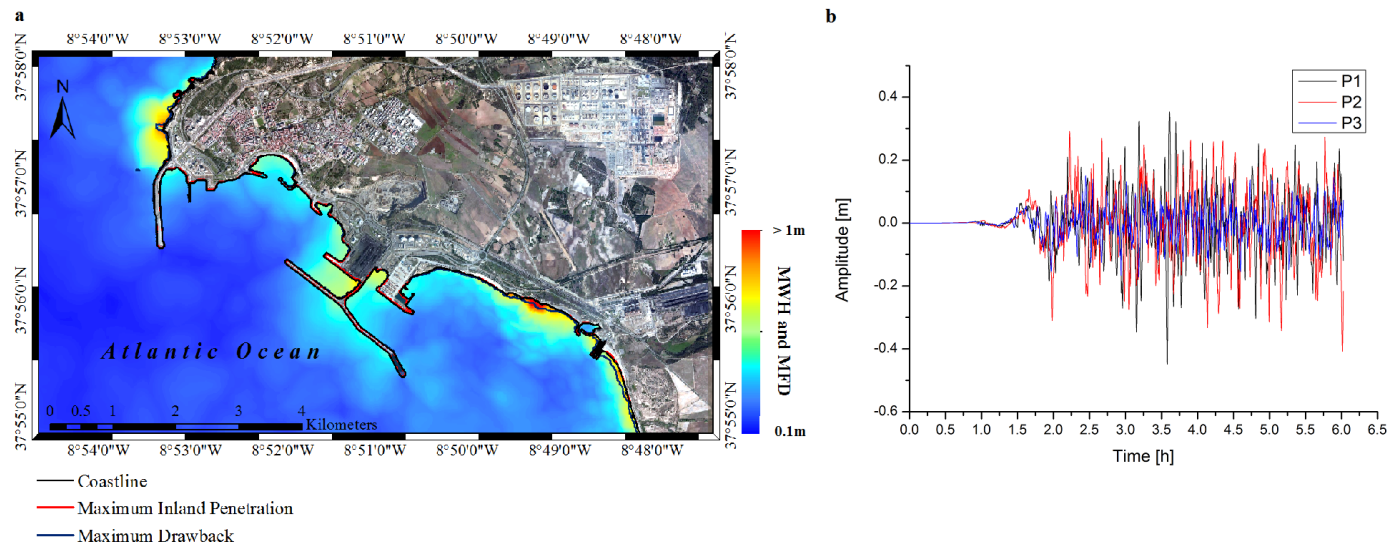

Figure 5. Panel (a): results for MWH, MFD, MDB, MIA, and MIP for the Gloria scenario at MSL: MWH and MFD are represented by the colour bar offshore and on land respectively. Offshore and land are separated by the coastline (black line). MDB is indicated by the blue line. The MIA is given between the coastline and the MIP (red line). Panel (b): synthetic waveform for $6 \mathrm{~h}$ propagation time at three chosen points (cf. Fig. 2) for the Gloria scenario.

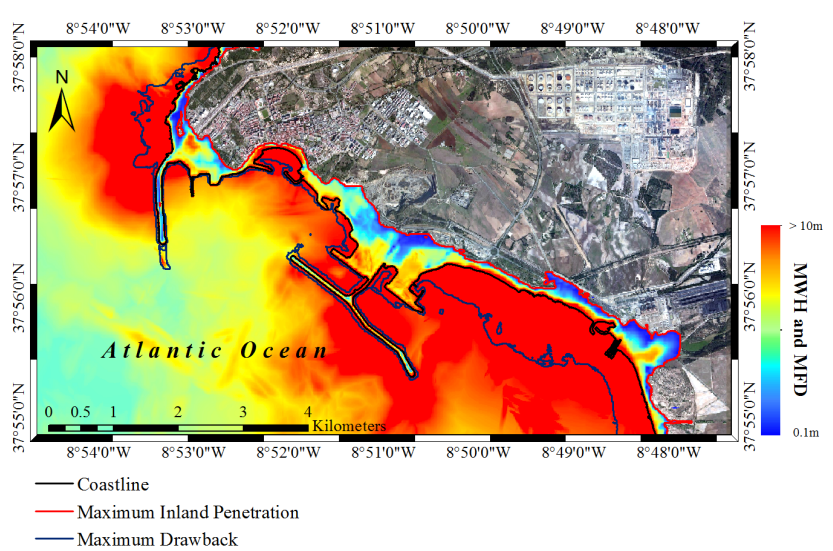

Figure 6. MWH, MFD, MDB, MIA, and MIP for the aggregate scenario considering all stages of the tide. MWH offshore and MFD on land are represented by the colour bar. MDB is indicated by the thick dark blue line. The MIA is given between the coastline (black line) and the MIP (red line).

once for all SWIM scenarios (Fig. 4). Attenuation is visible for all scenarios after $6 \mathrm{~h}$ runtime except for the Gloria scenario, where attenuation occurs after $15 \mathrm{~h}$.

\subsection{The aggregate scenario and the influence of the tide}

The aggregate scenario map depicts the extreme hazard values field point by taking the envelope of all individual scenarios. We present aggregate scenarios of MWH, MFD, MDB, MIA, and MIP for the different tide conditions (Fig. 6).

The aggregate scenario map (Fig. 6), considering all stages of the tide, shows $4.8 \mathrm{~km}^{2} \mathrm{MDB}$ area and $4.1 \mathrm{~km}^{2}$ MIA. Maximum run-up values over $20 \mathrm{~m}$ occur close to the cliffs at Vasco da Gama beach and are reached in MHHW conditions. In other areas, such as behind the liquid-bulk and petrochem-

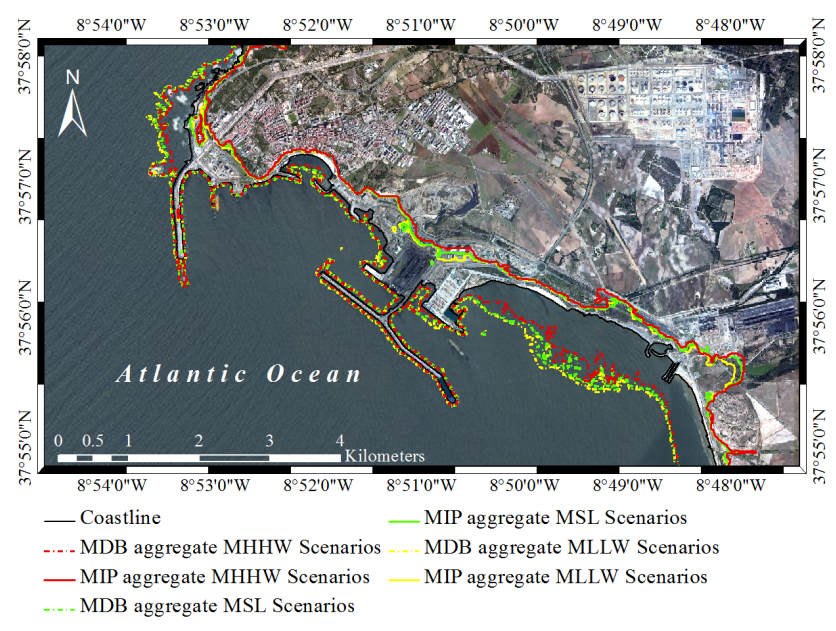

Figure 7. MDB and MIP limits for the stages MLLW, MSL, and MHHW of the tide.

ical terminal and at the railway connection to the port, maximum run-up values exceed $15 \mathrm{~m}$. MWHs above $10 \mathrm{~m}$ have been modelled along the entire coastline (Fig. 6). In high-tide conditions the inundation area is over $4 \mathrm{~km}^{2}$ and in low-tide conditions it is $3.5 \mathrm{~km}^{2}$ respectively, considering the aggregate scenario. The inundation area is $5 \%$ bigger at MSL and $14 \%$ at MHHW compared to MLLW (Fig. 7). MDB area is $16 \%$ greater at MLLW and $11 \%$ greater at MSL than in MHHW conditions (Fig. 7). The flooded area at Vasco da Gama beach is not significantly bigger at MHHW as the area behind the beach is confined by the steep topography. Moreover, Fig. 6 shows that the mean MFD values are about $1.5 \mathrm{~m}$ higher at MHHW than at MLLW in the area of the beach. Other areas behind the multipurpose and container terminal or at São Torpes beach clearly show greater inundation areas in high-tide conditions (Fig. 7). The limits of MDB and 
MIP for the aggregate scenario concerning MLLW, MSL, and MHHW are mapped in Fig. 7.

\section{Discussion and conclusions}

We ran a total of 18 scenarios to study the tsunami impact at Sines. Our results show that all SWIM scenarios cause severe inundation and drawback. To complement the integrated hazard maps of MWH, MFD, MDB, MIA, and MIP, we recorded synthetic waveforms at chosen points (see Fig. 2). The signals of the waveforms are diverse. This fact may be explained due to differences in the parameters of the TFs. Waveforms from HSF, MPF, GBF, and HSMPF are comparable in terms of period and arrival time (Fig. 4a-e). These TFs are dextral reverse with SW-NE trending and the hanging block in the SE. They are all located in the SWIM area. They are distinguishable by their dimensions and slip. Other parameters like the fault strike, dip, and rake are similar. Among the singlefault scenarios, the GBF is the largest fault, producing an MWH of $17.1 \mathrm{~m}$ in the study area (see Table 2). The HSF, although smaller, produces a similar inundation and wave height pattern as the slip is $5 \mathrm{~m}$ higher compared to the GBF (see Table 1). The MPF is smaller in terms of dimensions and has a slip of $8 \mathrm{~m}$ and therefore produces the weakest tsunami in Sines among the SWIM scenarios (Table 1 and Fig. 3e). Nevertheless, MWHs are above $10 \mathrm{~m}$ and MPF is the nearest fault to the test site that produces a short tsunami travel time ( $22 \mathrm{~min}$ in Fig. 4e). The composite scenario HSMPF is the worst-case scenario and combines the effects of both faults: the first wave arrives $22 \mathrm{~min}$ after the earthquake, and the tsunami triggered by HSMPF causes the worst inundation and drawback in Sines. The CWF is a subduction slab and has different fault parameters compared to the other TFs in the SWIM. The shallow, east-dipping slab has dimensions of $170 \times 200 \mathrm{~km}$ and a slip of $20 \mathrm{~m}$ (see Table 1). The analysis of the waveforms shows that wave periods generated by the CWF are larger than those generated by the other TFs in the SWIM. This fact may be explained by the larger co-seismic deformed area in this scenario. Cape St. Vincent (Fig. 1b), in the southwest of Portugal, might act as an obstacle to the tsunami leading to a reduced impact. The CWF has a higher impact in the southern part of the study area but with decreasing inundation and amplitudes towards the north. Nevertheless, wave amplitudes of $5 \mathrm{~m}$ cause considerable inundation in the northern part of the port. The waves produced by CWF reach Sines $38 \mathrm{~min}$ after the earthquake (Table 2). The Gloria Fault scenario located at $37^{\circ} \mathrm{N}$ between $14^{\circ} \mathrm{W}$ and $24^{\circ} \mathrm{W}$ produces the smallest inundation in the study area. It is a transform fault triggering slight vertical movement because of a $160^{\circ}$ rake with a slip of $11 \mathrm{~m}$ (Table 2). The scenario produces amplitudes between 0.3 and $0.4 \mathrm{~m}$ with approximately a $10 \mathrm{~min}$ period (Fig. $5 \mathrm{~b}$ ). The earthquake in 1941 generated similar waveforms, showing weak attenuation with amplitudes around $0.4 \mathrm{~m}$ in Cascais (Baptista et al.,
1992; Baptista and Miranda, 2009). Site effects, observed in some few coastal locations (Fig. 5a), caused MWH over $1 \mathrm{~m}$ with some smaller inundation in uninhabited area between the container terminal and the intake and restitution points of the EDP power plant. Because of the larger distance to the Portuguese coast, the tsunami travel time is approximately 85 min (Table 2).

We also calculated flow velocities for the composite scenario HSMPF at MSL for different stages of tsunami propagation. The median values are about $10 \mathrm{~m} \mathrm{~s}^{-1}$ in the inundation area at all terminals in the port. Some extremes of about $20 \mathrm{~m} \mathrm{~s}^{-1}$ or higher occur close to the breakwaters, jetties, and in the inundation area when the flow depth values are small depending on the considered propagation instant. In general, we find that flow velocities increase with lower flow depth values in the inundation area.

Considering the HSMPF scenario in MSL conditions, the pipelines at the liquid-bulk and petrochemical terminal are entirely inundated, with up to $5 \mathrm{~m}$ flow depth values. These structures are subject to flow velocities of about $10 \mathrm{~m} \mathrm{~s}^{-1}$ at first wave impact. At the $17 \mathrm{~m}$ topographic contour, the pipelines behind the liquid-bulk and petrochemical terminal are not affected by the tsunami (Fig. 3d). We find similar flow velocity values at the multipurpose terminal where the pipelines of the liquefied natural gas storage tanks pass. Here the maximum flow velocity values are slightly above $10 \mathrm{~m} \mathrm{~s}^{-1}$ at wave impact, and MFDs are between 5 and $10 \mathrm{~m}$. The conveyor belt and the stockpiles at the multipurpose terminal are nearly entirely inundated up to a water level of $5 \mathrm{~m}$ and show flow velocities of $10 \mathrm{~m} \mathrm{~s}^{-1}$ at first wave impact. The pipelines at the liquid-bulk, petrochemical, and multipurpose terminal are inundated in all scenarios in the SWIM. These quantitative DTHA results indicate a high risk of potential damage in the case of tsunami impact. However, the topic of building vulnerability is beyond the scope of this study.

The tide has an important influence on tsunami impact in Sines. The tidal regime is semi-diurnal with an amplitude of about $2 \mathrm{~m}$. As expected, the aggregate scenario in MHHW conditions caused larger inundation areas and higher MFD values. On the other hand, the aggregate scenario at MLLW produced larger drawback areas. A tsunami impact at low tide does not exclude the risk of heavy inundation and increases MDB by $16 \%$ compared to MHHW (Fig. 7).

Our results are compatible with the PTHA (probabilistic tsunami hazard assessment) results for the northeast Atlantic, recently published by Omira et al. (2015). This study shows that wave heights exceeding $5 \mathrm{~m}$ have a probability of $45 \%$ of occurrence in 500 years at Sines. Only the scenarios of the SWIM area have the capacity to produce such a high tsunami impact along the Portuguese west coast. Moreover, our results are comparable with the unique historical report showing that the tsunami did not reach the city (Falcão, 1987).

We computed a map showing the contribution of the individual scenarios to the aggregate scenario at MSL (Fig. 8). 
Table 3. Contribution of the scenarios considering MWH and MFD to the aggregate model at the three stages of the tide.

\begin{tabular}{lrrrl}
\hline Scenario & $\begin{array}{r}\text { CWF } \\
(\%)\end{array}$ & $\begin{array}{r}\text { GBF } \\
(\%)\end{array}$ & $\begin{array}{r}\text { HSF } \\
(\%)\end{array}$ & $\begin{array}{l}\text { HSMPF } \\
(\%)\end{array}$ \\
\hline AGG MHHW & 8.3 & 15.8 & 9.9 & 66 \\
AGG MSL & 15.1 & 12.4 & 10.0 & 62.5 \\
AGG MLLW & 16.8 & 11.7 & 11.1 & 60.3 \\
\hline
\end{tabular}

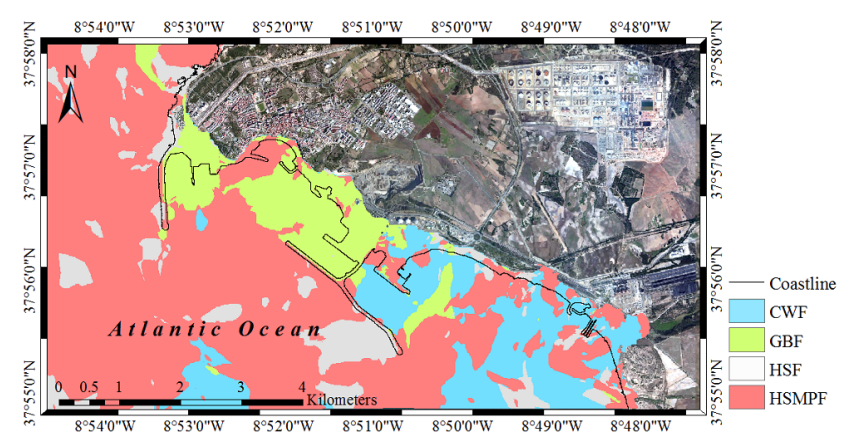

Figure 8. Contribution of individual scenarios considering MWH and MFD to the aggregate model at MSL.

Four scenarios contribute to the aggregate scenario, namely CWF, GBF, HSF, and HSMPF. The main factor in the aggregate model is the HSMPF scenario that contributes more than $60 \%$ in terms of MWH and MFD area, independent of the tidal amplitude (Table 3). The scenarios CWF, GBF, and HSF contribute about $12 \pm 4 \%$ to the aggregate model. The MPF and Gloria do not contribute to the aggregate scenario (Table 3 and Fig. 8).

Finally, we simulate the extreme scenario corresponding to the combination of the worst seismic scenario (HSMPF) and the highest annual tide ( $2 \mathrm{~m}$ above MSL). The annual frequency of occurrence of the HSMPF seismic scenario magnitude 8.75 is $8 \times 10^{-4}$ (Omira et al., 2015) - and the annual frequency of the extreme tide is 1 , resulting in a very unlikely event but corresponding to the worst tsunami impact at Sines. On the other hand, the probability of having a tsunami in MHHW conditions is much higher than the probability of having a tsunami in extreme tide conditions because the MHHW tide level occurs several times a year. In Fig. 9, we show a comparison between the MIPs for HSMPF in MHHW conditions, HSMPF in extreme annual tide conditions, and the aggregate scenario. The results show that the inundation area for the extreme scenario is $5 \%$ higher than the one in MHHW conditions. However, the comparison between the extreme scenario and the aggregate results in a $0.5 \%$ greater inundated area. Therefore, we recommend considering the $5 \%$ as an additional buffer regarding inland penetration when applying mitigation measures.

In conclusion, we find that all SWIM scenarios (CWF, GBF, HSF, MPF, and HSMPF) demonstrate a high impact at

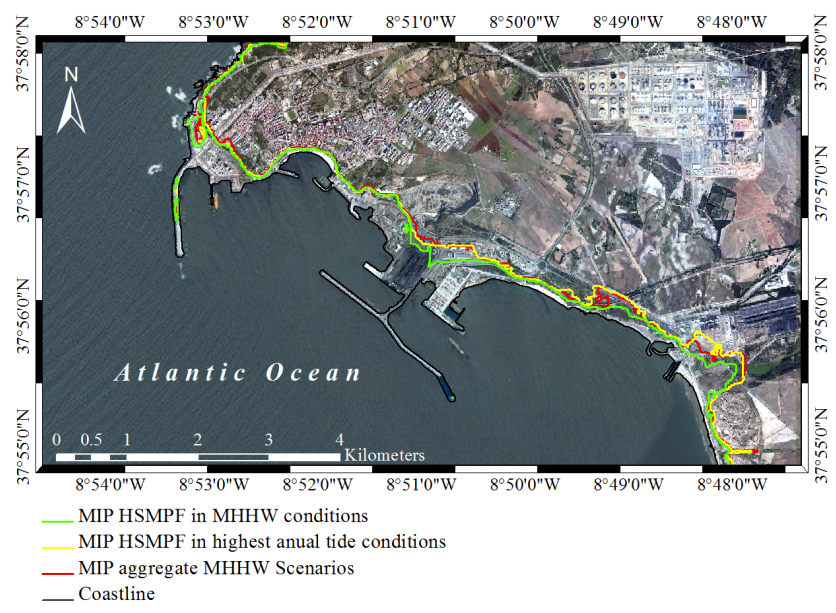

Figure 9. Comparison between the inundation extents (MIP) for HSMPF at MHHW, HSMPF at highest annual tide, and the aggregate scenario.

Sines test site. Nevertheless, the weakest source, the MPF, still causes considerable inundation and an MWH above $10 \mathrm{~m}$. The proximity of the faults within the SWIM results in short tsunami travel times. For the scenarios MPF and HSMPF, we calculated $22 \mathrm{~min}$ propagation time from the source to the Sines test site. This closeness to possible tsunami sources creates the need for an efficient early warning system and meticulously planned evacuation for the port and other coastal areas. Also, coastal societies need to be educated about and prepared for possible tsunami impact.

The Gloria Fault scenario differs from the other scenarios and produces an MWH of approximately $1 \mathrm{~m}$ in certain areas, 1 order of magnitude less than the scenarios in the SWIM.

The aggregate scenario allows us to consider a set of faults to produce a synthesis of different scenarios. We further state the importance of this tool as an important indicator for evacuation and city planners. We showed with the contribution map that different sources have varying degrees of importance in our study area. Although the worst-case scenario may contribute more to the aggregate scenario than the other faults considered, the other faults may still have a more significant impact on other parts of the test site. The aggregate scenario is a valuable tool for quantitative presentation of tsunami impact from multiple sources. Especially in areas exposed to threat from near-field sources, the aggregate scenario maps help to establish accurate evacuation plans and thus to allow efficient and faster reaction to tsunami warning.

Acknowledgements. This work is funded by ASTARTE - Assessment, Strategy And Risk Reduction for Tsunamis in Europe - FP7-ENV2013 6.4-3, Grant 603839. The authors wish to thank Commandant José Brazuna Fontes of Sines harbour for his support of the field survey and Direção-Geral do Território for making available LIDAR data of the study area. Finally, the authors wish to 
thank the reviewers for their suggestions, which greatly improved the paper.

Edited by: I. Didenkulova

Reviewed by: two anonymous referees

\section{References}

Antunes C.: Tabelas de Máximos, Médias e Mínimos, available at: http://webpages.fc.ul.pt/ cmantunes/hidrografia/hidro_ tabelas.html, last access: 18 November 2014.

Atillah, A., El Hadani, D., Moudni, H., Lesne, O., Renou, C., Mangin, A., and Rouffi, F.: Tsunami vulnerability and damage assessment in the coastal area of Rabat and Salé, Morocco, Nat. Hazards Earth Syst. Sci., 11, 3397-3414, doi:10.5194/nhess-113397-2011, 2011.

Baptista, M. A. and Miranda, J. M.: Revision of the Portuguese catalog of tsunamis, Nat. Hazards Earth Syst. Sci., 9, 25-42, doi:10.5194/nhess-9-25-2009, 2009.

Baptista, M. A., Miranda, P., and Victor, L. M.: Maximum entropy analysis of Portuguese tsunami data; the tsunamis of 28.02.1969 and 26.05.1975, Sci. Tsunami Hazards, 10, 9-20, 1992.

Baptista, M. A., Miranda, P. M. A., Miranda, J. M., and Victor, L. M.: Constrains on the source of the 1755 Lisbon tsunami inferred from numerical modelling of historical data on the source of the 1755 Lisbon tsunami, J. Geodyn., 25, 159-174, 1998.

Baptista, M. A., Miranda, J. M., Omira, R., and Antunes, C.: Potential inundation of Lisbon downtown by a 1755-like tsunami, Nat. Hazards Earth Syst. Sci., 11, 3319-3326, doi:10.5194/nhess-113319-2011, 2011a.

Baptista, M. A., Miranda, J. M., Batllo, J., and Macia, R.: North East Atlantic Tsunamis Related with Gloria Fault, AGU Fall Meeting Abstracts, 1, 1530, 2011b.

Benchekroun, S., Omira, R., Baptista, M. A., El Mouraouah, A., Brahim, A. I., and Toto, E. A.: Tsunami impact and vulnerability in the harbour area of Tangier, Morocco. Geomatics, Nat. Hazards Risk, 6, 718-740, doi:10.1080/19475705.2013.858373, 2015.

Câmara Municipal de Sines: Munícipio de Sines, available at: http://www.sines.pt/PT/Negocios/potencialidades/turismo/ Paginas/default.aspx (last access: 18 September 2014), 2007.

Debrach, J.: Raz de marée d'origine sismique eneregistrée sur le litoral Atlantique du Maroc, Service de Physique du Globe et de Meteorologie, Annales, Maroc, 1946.

Direção-Geral do Território: Modelo Digital do Terreno das Zonas Costeiras de Portugal Continental com resolução de $2 \mathrm{~m}(600 \mathrm{~m}$ mar, 400 m terra) - LiDAR, Direção de Serviços de Geodesia e Informação Geográfica, Direção-Geral do Território (DGT), Lisboa, 2011 .

Falcão, J., A.: Memória paroquial do Concelho de Sines em 1758, Real Soc. Arq. Lusitana, Santiago do Cacém, 1987.

Fukao, Y.: Thrust faulting at a lithospheric plate boundary the Portugal earthquake of 1969, Earth Planet. Sc. Lett., 18, 205-216, 1973.

GEBCO: The General Bathymetric Chart of the Oceans, GEBCO_2014 Grid, version 20150318, available at: http://www. gebco.net, last access: July 2014.
Gràcia, E., Dañobeitia, J., Vergés, J., and PARSIFAL Team.: Mapping active faults offshore Portugal $(36 \mathrm{~N}-38 \mathrm{~N})$ : implications for seismic hazard assessment along the southwest Iberian margin, Geology, 31, 83-86, 2003.

Grimison, N. L. and Chen, W. P.: The Azores-Gibraltar plate boundary: Focal mechanisms, depths of earthquakes, and their tectonic implications, J. Geophys. Res.-Solid, 91, 2029-2047, 1986.

Gutenberg, B. and Richter, C. F.: Seismicity of the Earth and associated phenomena, Princeton University Press, Princeton, New Jersey, 1949.

Gutscher, M. A., Malod, J., Rehault, J. P., Contrucci, I., Klingelhoefer, F., Mendes-Victor, L., and Spakman, W.: Evidence for active subduction beneath Gibraltar, Geology, 30, 1071-1074, 2002.

Instituto Hidrográfico de Portugal: Aproximações a Sines. Plano de Porto de Sines no. 26408, 3rd Edn., Marinha, Instituto Hidrográfico, Lisbon, 2010.

Instituto Hidrográfico de Portugal: Bathymetric Model of Sines, Modelo Batimetrico de Sines, available at: http://www.hidrografico.pt/download-gratuito.php (last access: 4 April 2014), 2012.

Instituto Nacional de Estatística: Census 2011, available at: $\mathrm{http} / / /$ censos.ine.pt/xportal/xmain?xpid=CENSOS\&xpgid= censos2011_apresentacao (last access: 18 September 2014), 2011.

Johnston, A. C.: Seismic moment assessment of earthquakes in stable continental regions- III. New Madrid 1811-1812, Charleston 1886 and Lisbon 1755, Geophys. J. Int., 126, 314-344, 1996.

Kaabouben, F., Baptista, M. A., Iben Brahim, A., El Mouraouah, A., and Toto, A.: On the moroccan tsunami catalogue, Nat. Hazards Earth Syst. Sci., 9, 1227-1236, doi:10.5194/nhess-9-1227-2009, 2009.

Laughton, A. S. and Whitmarsh, R. B.: The Azores-Gibraltar plate boundary, in: Geodynamics of Iceland and the North Atlantic area, NATO Advanced Study Institute, Reykjavik, Springer, the Netherlands, 63-81, 1974.

Lemos, C. R., Omira, R., Pinheiro, L. M., Baptista, M. A., Quaresma, L. S., and Garrido, C.: Tsunami Impact from a 1755like event in the Aveiro Region, Portugal, EGU General Assembly Conference Abstracts, 16, 15629, 2014.

Lima, V. V., Miranda, J. M., Baptista, M. A., Catalão, J., Gonzalez, M., Otero, L., Olabarrieta, M., Álvarez-Gómez, J. A., and Carreño, E.: Impact of a 1755-like tsunami in Huelva, Spain, Nat. Hazards Earth Syst. Sci., 10, 139-148, doi:10.5194/nhess10-139-2010, 2010.

Liu, P. L. F., Cho, Y. S., Briggs, M. J., Kanoglu, U., and Synolakis, C. E.: Runup of solitary waves on a circular island, J. Fluid Mech., 302, 259-285, 1995.

Liu, P. L., Woo, S. B., and Cho, Y. S.: Computer programs for tsunami propagation and inundation, Cornell University, available at: http://tsunamiportal.nacse.org/documentation/ COMCOT_tech.pdf (last access: 25 May 2015), 1998.

Luis, J. F.: Mirone: A multi-purpose tool for exploring grid data, Comput. Geosci., 33, 31-41, 2007.

Luque, L., Lario, J., Zazo, C., Goy, J. L., Dabrio, C. J., and Silva, P. G.: Tsunami deposits as paleoseismic indicators: examples from the Spanish coast, Acta geológica hispánica, 36, 197-211, 2001.

Lynnes, C. S. and Ruff, L. J.: Source process and tectonic implications of the great 1975 North Atlantic earthquake, Geophys. J. Int., 82, 497-510, 1985. 
Martins, I. and Mendes-Víctor, L. A.: Contribuição para o estudo da sismicidade de Portugal Continental, Instituto Geofísico do Infante D. Luís, Edição 18 de Publicação, Universidade de Lisboa, Liboa, 1990.

Matias, L. M., Cunha, T., Annunziato, A., Baptista, M. A., and Carrilho, F.: Tsunamigenic earthquakes in the Gulf of Cadiz: fault model and recurrence, Nat. Hazards Earth Syst. Sci., 13, 1-13, doi:10.5194/nhess-13-1-2013, 2013.

Mendonça, J. M.: História Universal dos Terramotos que tem havido no mundo desde que ha noticia, desde a sua criação até ao século presente, Arq Nac da Torre de Tombo, Lisboa, Portugal, 1758.

Miranda, J. M., Baptista, M. A., Terrinha, P., and Matias, L.: Tsunamigenic source areas for Portugal mainland, Iberia, Oral Communication, Session on Tsunami Early Warning Systems and Tsunami Risk Mitigation in the European-Mediterranean Region, 31st General Assembly of the European Seismological Commission, Crete, Greece, 2008.

Miranda, J. M., Luis, J. F., Reis, C., Omira, R., and Baptista, M. A.: Validation of NSWING, a multi-core finite difference code for tsunami propagation and run-up, Paper Number S21A-4390, Session Number and Title S21A, Natural Hazards, American Geophysical Union (AGU) Fall Meeting, San Francisco, 2014.

Moreira, V. S.: Sismicidade histórica de Portugal Continental, Rev. Inst. Nac. Met. e Geofísica, Março, 1984, 3-79, 1984.

Okada, Y.: Surface deformation due to shear and tensile faults in a half-space, Bull. Seismol. Soc. Am., 75, 1135-1154, 1985.

Omira, R., Baptista, M. A., Matias, L., Miranda, J. M., Catita, C., Carrilho, F., and Toto, E.: Design of a Sea-level Tsunami Detection Network for the Gulf of Cadiz, Nat. Hazards Earth Syst. Sci., 9, 1327-1338, doi:10.5194/nhess-9-1327-2009, 2009.

Omira, R., Baptista, M. A., Miranda, J. M., Toto, E., Catita, C., and Catalao, J.: Tsunami vulnerability assessment of CasablancaMorocco using numerical modelling and GIS tools, Nat. Hazards, 54, 75-95, 2010.

Omira, R., Baptista, M. A., and Miranda, J. M.: Evaluating tsunami impact on the Gulf of Cadiz coast (Northeast Atlantic), Pure Appl. Geophys., 168, 1033-1043, 2011.
Omira, R., Baptista, M. A., Leone, F., Matias, L., Mellas, S., Zourarah, B., Miranda, J. M., Carrilho, F., and Cherel, J.-P.: Performance of coastal sea-defense infrastructure at El Jadida (Morocco) against tsunami threat: lessons learned from the Japanese 11 March 2011 tsunami, Nat. Hazards Earth Syst. Sci., 13, 1779 1794, doi:10.5194/nhess-13-1779-2013, 2013.

Omira, R., Baptista, M. A., and Matias, L.: Probabilistic Tsunami Hazard in the Northeast Atlantic from Near- and Far-Field Tectonic Sources, Pure Appl. Geophys., 172, 901-920, 2015.

Porto de Sines: Administração dos portos de Sines e do Algarve S.A., available at: http://www.portodesines.pt/, last access: 18 September 2014.

Renou, C., Lesne, O., Mangin, A., Rouffi, F., Atillah, A., El Hadani, D., and Moudni, H.: Tsunami hazard assessment in the coastal area of Rabat and Salé, Morocco, Nat. Hazards Earth Syst. Sci., 11, 2181-2191, doi:10.5194/nhess-11-2181-2011, 2011.

Ribeiro, A., Mendes-Victor, L., Cabral, J. M. L. C., Matias, L., and Terrinha, P.: The 1755 Lisbon earthquake and the beginning of closure of the Atlantic, Eur. Rev., 14, 193-205, 2006.

Solares, J. M. and Arroyo, A. L.: The great historical 1755 earthquake. Effects and damage in Spain, J. Seismol., 8, 275-294, 2004.

Tinti, S., Tonini, R., Bressan, L., Armigliato, A., Gardi, A., Guillande, R., Valencia, N., and Scheer, S.: Handbook of tsunami hazard and damage scenarios, JRC scientific and technical reports, EUR 24691 EN, JRC61463, Luxembourg, doi:10.2788/21259, 2011.

Zitellini, N., Chierici, F., Sartori, R., and Torelli, L.: The tectonic source of the 1755 Lisbon earthquake and tsunami, Ann. Geofis., 42, 49-55, 1999.

Zitellini, N., Mendes, L. A., Cordoba, D., Danobeitia, J., Nicolich, R., Pellis, G., and Ruiz, A. Z.: Source of 1755 Lisbon earthquake and tsunami investigated, Eos T. Am. Geophys. Union, 82, 285 291, 2001.

Zitellini, N., Gràcia, E., Matias, L., Terrinha, P., Abreu, M. A., DeAlteriis, G., and Diez, S.: The quest for the Africa-Eurasia plate boundary west of the Strait of Gibraltar, Earth Planet. Sc. Lett., 280, 13-50, 2009. 